\title{
EVALUASI KESUKSESAN IMPLEMENTASI OM SPAN MENGGUNAKAN MODEL DELONE DAN MCLEAN
}

\author{
M. Ichsana, Suryo Sujokob, Muhamad Gunturc, Wida Choirunnisad. \\ aBPPK, Jl. Purnawarman No. 99 Kebayoran Baru Jakarta Selatan. Email: ichsan.oke@gmail.com \\ b DJPB, Gd. Prijadi Praptosuhardjo Lt. 3, Jl. Wahidin II No. 3, Jakarta Pusat. Email: suryo.sujoko@kemenkeu.go.id c \\ BPPK, JI. Purnawarman No. 99 Kebayoran Baru Jakarta Selatan. Email: muhamadg@gmail.com \\ d BPPK, JI. Purnawarman No. 99 Kebayoran Baru Jakarta Selatan. Email: choirs.22@gmail.com
}

\section{INFO ARTIKEL}

SEJARAH ARTIKEL

Diterima Pertama

8 April 2017

Dinyatakan Dapat Dimuat 6 November 2017

\section{KATA KUNCI:}

IS Success Models, OM SPAN,

DeLone and McLean Model.

\section{ABSTRAK}

This study discusses DeLone and McLean Model to measure of the implementation of Online Monitoring (OM) SPAN and factors that affect success. OM SPAN is a web-based application used to monitor the planning and execution of the State Budget (APBN). OM SPAN developed and managed by the Directorate General of Treasury. Users OM SPAN as many 50s of thousands scattered nationwide from all work units of the central government. The results of this study indicate the successful implementation of information systems OM SPAN at $83 \%$ level ("Very Success"). Based on the analysis, researchers found that the information quality, system quality, and service quality simultaneously affect the user satisfaction of $44.1 \%$. Furthermore, user satisfaction affects the net benefit of users amounted to $63.7 \%$. The study also found that the system quality is the significant positive effect on user satisfaction. This needs to be considered by the organization for the development of OM SPAN in the future.

Penelitian ini membahas Model DeLone dan McLean untuk mengukur kesuksesan implementasi OM SPAN dan faktor-faktor yang memengaruhi kesuksesan. OM SPAN merupakan aplikasi berbasis web yang digunakan untuk memantau perencanaan dan pelaksanaan Anggaran Pendapatan dan Belanja Negara (APBN). OM SPAN dikembangkan dan dikelola oleh Direktorat Jenderal Perbendaharaan. Pengguna OM SPAN sebanyak 50 -an ribu yang tersebar secara nasional dari seluruh satuan kerja pemerintah pusat. Hasil dari penelitian ini menunjukan bahwa tingkat kesuksesan implementasi OM SPAN berada pada tingkat $83 \%$ ("Sangat Sukses"). Berdasarkan hasil analisis, peneliti menemukan bahwa kualitas informasi, kualitas sistem dan kualitas layanan memengaruhi kepuasan pengguna sebesar $44,1 \%$. Selanjutnya, kepuasan pengguna memengaruhi keuntungan bersih sebesar $63,7 \%$. Penelitian ini juga menemukan bahwa kualitas sistem berpengaruh positif signifikan terhadap kepuasan pengguna. Hal ini perlu dipertimbangkan oleh organisasi untuk pengembangan OM SPAN pada masa depan.

\section{PENDAHULUAN}

Pemanfaatan Teknologi Informasi dapat memberikan nilai tambah bagi organisasi jika didesain menjadi sistem informasi yang efektif dan efisien. Namun demikian, pengukuran atau penilaian kualitas sistem informasi sulit dilakukan (Furukawa \& Minami, 2013). Hal ini mendorong para peneliti mengembangkan model untuk menilai kesuksesan sebuah sistem, penelitian mengenai analisis pengaruh implementasi sistem terhadap organisasi, dan faktor-faktor yang dapat memengaruhi kesuksesan atau kegagalan implementasi tersebut. Salah satu model yang populer adalah DeLone and McLean dengan sebutan Information System Success Model. Model ini terdiri dari beberapa komponen, yaitu information quality, system quality, service quality, use, user satisfaction dan net benefit. Information System Success Model sudah banyak digunakan oleh para peneliti untuk mengukur kesuksesan penerapan suatu sistem informasi (McGill, Hobbs, \& Klobas, 2003), (Livari, 2005), (Petter, Delone, \& McLean, 2008), (Istianingsih

\& Wijanto, 2008), (Wahyuni, 2011), (Utami \& Samopa, 2013), (Pramadani \& Mudjahidin, 2013), (Sulistyo, 
2013), dan (Kanwal \& Rehman, 2016).

Penelitian tentang pengukuran kesuksesan e-government dan sistem informasi (Livari, 2005) membuktikan bahwa kesuksesan sistem informasi dipengaruhi oleh kualitas sistem informasi dan kualitas informasi hasil dari sistem tersebut. Penggunaan sistem informasi yang baik mampu memberikan kepuasan pengguna dan berdampak positif pada organisasi (Wahyuni, 2011). Menurut Pramadani \& Mudjahidin (2013) implementasi e-government mampu memangkas waktu yang digunakan.

Di Kementerian Keuangan terdapat sistem informasi yang digunakan secara nasional untuk pengelolaan Anggaran Pendapatan dan Belanja Negara (APBN). Sistem informasi tersebut adalah Online Monitoring Sistem Perbendaharaan dan Anggaran Negara (OM SPAN). OM SPAN adalah aplikasi berbasis web yang dapat diakses melalui jaringan internet untuk memantau perencanaan dan pelaksanaan APBN. OM SPAN dibangun dan dikelola oleh Ditjen Perbendaharaan sebagai solusi atas kebutuhan stakeholder SPAN untuk mendapatkan informasi dari basis data Enterprise Resource Planning (ERP) SPAN secara cepat, tepat, andal dan user friendly. Pengguna OM SPAN terdiri dari internal dan eksternal Kementerian Keuangan Republik Indonesia dengan jumlah 50-an ribu. Pengguna mendapatkan manfaat dari OM SPAN berupa akurasi informasi untuk pengambilan keputusan, kemudahan pengawasan APBN, kelancaran pelaksanaan APBN, dan sumber data penyusunan laporan. Basis data $O M$ SPAN diperbarui secara periodik per jam dari database ERP SPAN. OM SPAN dapat diakses melalui web di alamat URL http://spanint.kemenkeu.go.id atau melalui aplikasi di smartphone.

Amanat Undang-Undang Nomor 17 Tahun 2003 tentang Keuangan Negara bahwa keuangan negara harus dikelola secara tertib, taat pada peraturan perundang-undangan, efisien, ekonomis, efektif, transparan, dan bertanggung jawab dengan memperhatikan rasa keadilan dan kepatutan. Adanya OM SPAN ini akan membantu dalam mewujudkan amanat tersebut. Oleh karenanya, pengembangan OM SPAN perlu terus dilakukan.

Pengembangan sistem informasi memerlukan usaha dan biaya yang tidak sedikit. Sesuai dengan amanat UU Keuangan Negara terkait pengelolaan keuangan negara secara efisien, ekonomis dan efektif, maka diperlukan kajian sebelum dilakukan pengembangan sistem informasi termasuk OM SPAN. Kajian dimaksud terkait evaluasi kesuksesan implementasi OM SPAN dan faktor-faktor yang memengaruhi kesuksesan implementasinya.

Penelitian ini merupakan kajian yang menjawab kebutuhan pengembangan OM SPAN ke depan. Dalam penelitian ini akan dibahas tingkat kesuksesan implementasi OM SPAN, faktor-faktor pendukung kesuksesannya, dan hubungan antarfaktor tersebut. Oleh karenanya, penelitian ini mengadopsi Information System Success Model DeLone dan McLean (2003) untuk mengevaluasi kesuksesan implementasi OM SPAN dan faktorfaktor yang memengaruhi kesuksesannya.

Hasil penelitian ini berupa informasi terkait tingkat kesuksesan implementasi OM SPAN dan halhal yang perlu ditingkatkan. Selain itu, penelitian ini juga memberikan informasi terkait faktor-faktor pendukung kesuksesan implementasi OM SPAN dan hubungan antarfaktor tersebut. Dengan demikian, hasil penelitian ini akan memudahkan dalam menetapkan arah pengembangan OM SPAN agar tepat sasaran, efisien, ekonomis, efektif dan mendatangkan banyak manfaat sebagaimana amanat UU Keuangan Negara Nomor 17 Tahun 2003.

\section{KERANGKA TEORITIS DAN PENGEMBANGAN HIPOTESIS}

\subsection{Sistem Informasi}

Sistem informasi adalah sistem buatan manusia yang pada umumnya terdiri dari sekumpulan komponen berbasis komputer yang terintegrasi dan komponen manual yang dibangun untuk mengumpulkan, menyimpan, dan mengelola data serta menyediakan output informasi kepada pengguna (Gelinas \& Dull, 2012). Definisi lain, sistem informasi adalah sekumpulan prosedur-prosedur yang sah, di mana data dikumpulkan, diproses menjadi informasi, dan disalurkan kepada pengguna (Hall, 2011). Menurut (Stair \& Reynolds, 2010) Sistem informasi adalah sekumpulan komponen yang saling berhubungan dimana komponen tersebut mengumpulkan, memanipulasi, menyimpan, dan menyebarkan data dan informasi serta menyediakan mekanisme timbal balik sedemikian rupa untuk memenuhi suatu tujuan.

\subsection{Pengukuran Tingkat Kesuksesan}

Menurut Purwanto (2007) dalam Utami dan Samopa (2013), pengukuran tingkat kesuksesan terbagi menjadi 5 tingkat seperti tampak pada Tabel 1. Utami dan Samopa (2013) mengadopsi model pengukuran tingkat kesuksesan Purwanto (2007) untuk mengukur tingkat kesuksesan Sistem Informasi Akademik.

Sedangkan teori tentang kesuksesan sistem informasi dikenalkan oleh DeLone dan McLean pada 
tahun 1992 dengan sebutan Information Systems Success Model (IS Success Model). Model ini memberikan pemahaman secara komprehensif tentang keberhasilan sistem informasi dengan mengidentifikasi faktor-faktor pendukung kesuksesan penerapan sistem. Faktor-faktor tersebut adalah information quality, system quality, use, user satisfaction, individual impact, dan organizational impact.

Tabel 1. Tingkat Kesuksesan

\begin{tabular}{|c|c|l|}
\hline Tingkat & $\begin{array}{c}\% \\
\text { Kesuksesan }\end{array}$ & \multicolumn{1}{c|}{ Makna } \\
\hline 1 & $0 \%-20 \%$ & Sangat tidak sukses \\
\hline 2 & $21 \%-40 \%$ & Tidak sukses \\
\hline 3 & $41 \%-60 \%$ & Cukup sukses \\
\hline 4 & $61 \%-80 \%$ & Sukses \\
\hline 5 & $81 \%-100 \%$ & Sangat sukses \\
\hline
\end{tabular}

Sumber: Purwanto (2007)

Pada tahun 2003, IS Success Model mengalami perkembangan terkait faktor atau dimensi untuk mengukur kesuksesan penerapan sistem informasi. Dimensi tersebut adalah information quality, system quality, service quality, use, user satisfaction dan net benefit (DeLone \& McLean, 2003). Hubungan antara dimensi pengukuran ini tampak pada Gambar 1.

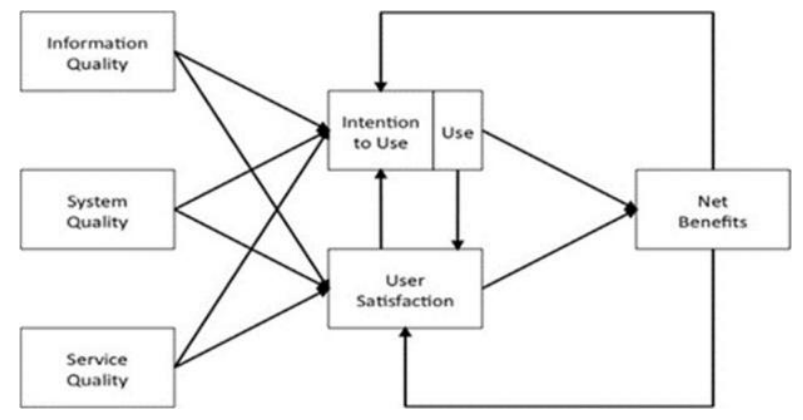

Gambar 1. Information Systems Success Model Sumber: DeLone dan McLean (2003)

Pada Gambar 1 tampak bahwa D\&M IS Success Model memiliki enam dimensi yang saling berhubungan. Detail enam dimensi tersebut adalah:

- System Quality - digunakan untuk mengukur kualitas sistem informasi dari software dan hardware. Kualitas sistem adalah kemampuan perangkat keras, perangkat lunak, kebijakan, prosedur dari sistem informasi untuk menyediakan informasi sesuai kebutuhan pengguna (DeLone \& McLean, 1992). Kualitas sistem diukur secara subyektif oleh pengguna, sehingga kualitas sistem yang digunakan adalah persepsi kualitas sistem (perceived system quality). Pengukuran kualitas sistem menggunakan indikator-indikator, yaitu; adaptability, availability, reliability, response time, usability, convenience of access, dan system integration.

- Information Quality - digunakan untuk mengukur kualitas keluaran dari sistem informasi (Jogiyanto, 2007). Kualitas informasi ini adalah kualitas informasi yang diukur secara subyektif oleh pengguna atau disebut persepsi kualitas informasi. Pengukuran kualitas informasi menggunakan indikator-indikator, yaitu completeness, ease of understanding, personalization, relevance, security, format of output, currency, dan precision.

- Service Quality - merupakan perbandingan antara harapan pengguna dengan layanan diterima. Terdapat tiga komponen yang memengaruhi kualitas layanan (service quality) , yaitu jaminan (assurance) kualitas yang diberikan sistem, kepedulian sistem (system empathy) terhadap pengguna, system responsiveness yaitu kualitas respon sistem terhadap permintaan pengguna (DeLone dan McLean, 2003). Pengukuran kualitas layanan menggunakan indikator-indikator, yaitu assurance, empathy dan responsiveness.

- Use - dibedakan untuk penggunaan keluaran (information use) dan penggunaan sistem (system use) (Jogiyanto, 2007). Pengukuran use dengan indikator-indikator, yaitu nature of use, navigation patterns, number of site visits, number of transactions executed.

- User Satisfaction - merupakan respon dan umpan balik dari pengguna setelah memakai sistem informasi. Sikap pengguna terhadap sistem informasi merupakan kriteria subjektif mengenai tingkat kepuasan pengguna terhadap sistem. Pengukuran kepuasan pengguna menggunakan indikator-indikator, yaitu repeat purchases, repeat visits, user surveys (DeLone dan McLean, 2003).

- Net Benefit - adalah hasil bersih atau keuntungan yang dirasakan oleh individu dan juga organisasi setelah menerapkan sistem informasi. Pengukuran net benefit menggunakan indikatorindikator, yaitu; cost savings, expanded markets, incremental additional sales, reduced search costs, tim saving, ease of job, effectiveness, speeds of accomplishing task, usefullness in work (Davis, 1989).

2.3. Structural Equation Model

Structural Equation Modelling (SEM) adalah 
sebuah evolusi dari model persamaan berganda yang dikembangkan dari prinsip ekonometri dan digabungkan dengan prinsip pengaturan dari psikologi dan sosiologi (Ghozali, 2008). Menurut Bowen dan Guo (2011), SEM merupakan kerangka untuk menguji moderasi model atau model untuk mengetahui variasi efek dari satu variabel dengan beberapa variabel lain sampai tingkat ketiga.

Menurut Ghozali (2008) dalam persamaan SEM terdiri beberapa variabel yaitu variabel eksogen (independen), variabel endogen (dependen), dan variabel mediasi (intervening). Variabel disebut eksogen jika posisi variabel dalam diagram model struktural tidak didahului oleh variabel sebelumnya. Variabel endogen jika posisi variabel dalam diagram model struktural didahului oleh posisi sebelumnya. Sedangkan variabel mediasi karena memiliki anteseden variabel yang mendahului dan konsekuen (variabel yang mengikuti).

Menurut Wiyono (2011) pendekatan dalam estimasi relasi pada SEM ada 2, yaitu covariance based (CB-SEM) dan variance based atau Partial Least Squares (PLS-SEM). CB-SEM cocok digunakan untuk pengujian dan pengembangan model. Namun jika terjadi ketidakpastian dari pendugaan skor faktor, maka akan menyebabkan menurunnya keakuratan prediksi. Sedangkan PLS-SEM cocok digunakan jika tujuan utamanya untuk prediksi. Model PLS-SEM merupakan alternatif untuk pemodelan persamaan struktural berbasis varian, di mana dalam analisis data tidak mengharuskan data terdistribusi normal dan bebas dari multikolinieritas (Garson, 2016).

\subsection{Kerangka Pemikiran dan Hipotesis}

IS Success Model Delone dan McLean telah digunakan banyak peneliti untuk mengukur kesuksesan implementasi sistem informasi (McGill, Hobbs, \& Klobas, 2003), (Livari, 2005), (Petter, Delone, \& McLean, 2008), (Istianingsih \& Wijanto, 2008), (Wahyuni, 2011), (Utami \& Samopa, 2013), (Pramadani \& Mudjahidin, 2013), (Sulistyo, 2013), dan (Kanwal \& Rehman, 2016). Hasil penelitian mereka di antaranya kualitas informasi secara signifikan memengaruhi kepuasan pengguna (Istianingsih \& Wijanto, 2008). Livari (2005) dan (Wahyuni, 2011) membuktikan bahwa kesuksesan sistem informasi dipengaruhi oleh kualitas sistem informasi dan kualitas informasi. Petter, Delone, dan McLean (2008) menemukan bahwa penambahan kualitas layanan membawa perubahan dalam penggunaan IS success model, terutama pengembangan fenomenal pada e-commerce.
Berdasarkan penelitian sebelumnya, maka kerangka pemikiran artikel ini adalah tampak pada Gambar 2.

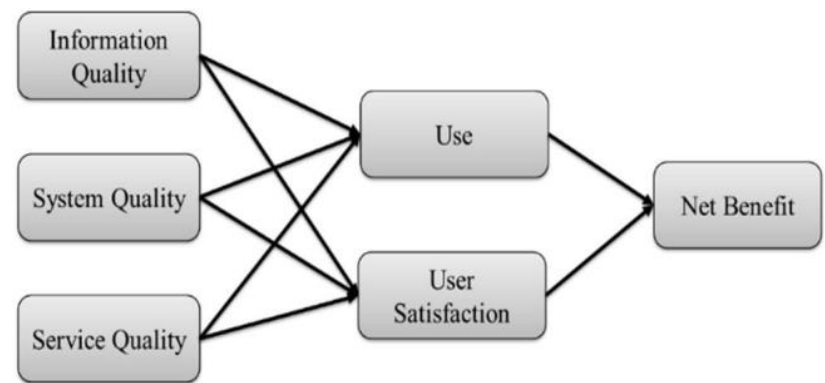

Gambar 2 Kerangka Pemikiran Penelitian

Kerangka pemikiran penelitian ini mendasari penyusunan kuesioner hasil modifikasi (DeLone \& McLean, 2003), (Davis, 1989) dan (Livari, 2005) sebagaimana terlampir (Lampiran I).

Hasil penelitian Baroudi, Olson, \& Ives (1986) Use berpengaruh tidak signifikan terhadap user satisfaction. Pendapat Baroudi, Olson, \& Ives (1986) juga didukung oleh penelitian Radityo \& Zulaikha (2007) dan McGill, Hobbs, dan Klobas (2003). Penelitian (Utami \& Samopa, 2013), dan (Kanwal \& Rehman, 2016) berhasil membuktikan bahwa kualitas informasi, kualitas sistem, dan kualitas layanan memengaruhi kesuksesan sistem informasi. Sulistyo (2013) menemukan bahwa kualitas informasi, kualitas sistem, dan kualitas layanan berpengaruh positif signifikan terhadap intensi peggunaan dan kepuasan pengguna. Sulistyo (2013) dan Utami \& Samopa (2013) juga menemukan bahwa kepuasan pengguna berpengaruh positif signifikan terhadap manfaat bersih yang diterimanya. Penelitian lain menemukan bahwa kepuasan pengguna dan penggunaan terelimasi dari IS Success Model karena sistem yang diteliti adalah bersifat mandatori (Sedera, Gable, \& Chan, 2004).

Berdasarkan hasil penelitian sebelumnya, maka hipotesis penelitian ini adalah:

H1 : Information Quality berpengaruh positif terhadap Use

H2 : Information Quality berpengaruh positif terhadap User Satisfaction

H3 : System Quality berpengaruh positif terhadap Use

H4 : System Quality berpengaruh positif terhadap User Satisfaction

H5 : Service Quality berpengaruh positif terhadap Use

H6 : Service Quality berpengaruh positif terhadap User Satisfaction

H7 : Use berpengaruh positif terhadap Net Benefit

H8 : User Satisfaction berpengaruh positif terhadap Net Benefit. 


\section{METODOLOGI PENELITIAN}

\subsection{Variabel Penelitian}

\subsubsection{Variabel Dependen}

Variabel dependen adalah variabel dipengaruhi oleh variabel independen (Wiyono, 2011). Variabel dependen atau endogen dalam model kesuksesan sistem informasi adalah:

- User Satisfaction (US) - adalah kepuasan dari pengguna OM SPAN atas aplikasi dan outputnya.

- Use (UI) - adalah penggunaan OM SPAN oleh pengguna akhir atas kesadaran dan keinginannya sendiri.

- Net Benefit (NB) - adalah manfaat bersih atau keutungan yang dirasakan oleh individu dan juga organisasi setelah menerapkan sistem informasi.

\subsubsection{Variabel Independen}

Variabel independen adalah variabel yang memengaruhi atau yang menyebabkan terjadinya perubahan terhadap variabel dependen (Wiyono, 2011). Variabel independen atau eksogen dalam model kesuksesan sistem informasi adalah:

- Information Quality (IQ) - adalah kualitas informasi yang diukur secara subyektif oleh pengguna atau disebut sebagai persepsi kualitas informasi.

- System Quality (SQ) - adalah kualitas sistem informasi yang merupakan kemampuan perangkat keras, perangkat lunak, kebijakan, prosedur dari sistem informasi untuk menyediakan informasi sesuai kebutuhan pengguna.

- Service Quality (SEQ) - adalah kualitas layanan yang merupakan perbandingan antara harapan pengguna dengan layanan yang diterimanya.

\subsection{Metode Pengumpulan Data}

Pengumpulan data penelitian ini menggunakan metode survei dengan instrumen penelitian berupa kuesioner (Lampiran I). Kuesioner tersebut merupakan modifikasi dan pengembangan penelitian (DeLone \& McLean, 2003), (Livari, 2005) dan (Davis, 1989). Kuesioner penelitian ini menggunakan skala Likert untuk mengukur persepsi responden terhadap indikator. Skala Likert terdiri dari lima tingkat preferensi jawaban yaitu; Sangat tidak setuju (1), Tidak Setuju (2), Netral (3), Setuju (4) dan Sangat Setuju (5). Selanjutnya, kuesioner berserta petunjuk pengisiannya dikirim kepada pengguna OM SPAN secara acak melalui email.

Kebutuhan pengambilan sampel menurut Hair et al. (1998) dalam Wiyono (2011) untuk model multivariate data analysis adalah 5 kali jumlah item pertanyaan pada kuesioner. Sedangkan untuk metode pemilihan sampelnya menggunakan random sampling. Hal ini berdasarkan Wiyono (2011), metode random sampling cocok digunakan jika karakteristik populasi homogen atau relatif homogen.

\subsection{Metode Analisis Data}

Metode analisis data yang digunakan adalah

SEM. Menurut Bacon (2009) kelebihan menggunakan SEM adalah:

a. SEM memberikan pengamatan yang lebih luas terhadap hubungan variabel laten dan variabel lainnya. Dengan menggunakan SEM dapat memodelkan variabel laten dengan beberapa variabel indikator penting dan melihat keandalan masing-masing indikatornya.

b. SEM lebih andal untuk menguraikan dan menganalisis setiap bagian yang dikembangkan sebuah model persamaan. Sedangkan analisis jalur dan regresi berganda hanya menjangkau bagian terluar dari sebuah model penelitian.

c. SEM mampu mengatasi data yang sulit, seperti data time series dengan kesalahan autokorelasi, data tidak tirdistribusi normal, dan data tidak lengkap. Dalam analisis menggunakan regresi berganda penanganan uji asumsi klasik (normalitas data, autokorelasi, multikolonieritas dan heteroske-dastisitas) sulit dilakukan jika sudah melibatkan variabel moderating atau intervening.

Penelitian ini termasuk penelitian konfirmatori, maka metode analisis data yang sesuai adalah CBSEM. Metode CB-SEM merupakan metode yang digunakan untuk mengkonfirmasi sebuah teori melalui pengujian hipotesis, terutama ketika jumlah data sampel besar, data terdistribusi secara normal, dan yang terpenting model memiliki landasan teoritis yang kuat (Wong, 2013).

Menurut Ghozali dan Fuad (2008) tahap pemodelan dan analisis CB-SEM terdiri dari 7 langkah, yaitu:

a. Konseptualisasi model. Konseptualisasi model adalah pencarian atau pengembangan sebuah model yang mempunyai dasar teoretis yang kuat. Selanjutnya, model tersebut divalidasi secara empirik melalui pemograman SEM.

Pengembangan sebuah teori yang berjustifikasi 
ilmiah adalah syarat utama dan pertama sebelum menggunakan permodelan SEM.

b. Menyusun diagram alur. Tahap ini merupakan visualisasi dari tahap pertama, di mana konseptualisasi model yang telah dibuat dalam bentuk diagram alur. Diagram alur ini mempermudah peneliti untuk melihat hubungan-hubungan kausalitas yang ingin diuji. Dalam permodelan SEM, peneliti biasanya bekerja dengan konsep yang memiliki pijakan teoretis yang cukup untuk menjelaskan berbagai bentuk hubungan.

c. Spesifikasi Model. Tahap ini adalah melakukan spesifikasi model dan menggambarkan sifat serta jumlah parameter yang diestimasi. Spesifikasi model ini menyusun hubungan antara variabel laten yang satu dengan variabel laten lainnya dan juga hubungan antara variabel laten dengan variabel manifest berdasarkan teori.

d. Identifikasi Model. Identifikasi Model adalah melakukan identifikasi kemungkinan diperolehnya nilai unik untuk setiap parameter pada model.

e. Estimasi parameter. Estimasi parameter merupakan estimasi terhadap model untuk menghasilkan nilai-nilai parameter menggunakan salah satu metode estimasi yang ada. Pemilihan metode estimasi seringkali ditentukan berdasarkan karakteristik dari variabel-variabel yang dianalisis.

f. Penilaian model fit. Penilaian model fit merupakan pengujian kecocokan antara model dengan data. Beberapa kriteria ukuran kecocokan atau Goodness of Fit (GOF) dapat digunakan untuk melaksanakan langkah ini.

g. Interpretasi dan modifikasi model. Interpretasi yaitu melihat besarnya kontribusi atau pengaruh variabel indikator terhadap variabel laten dan besarnya pengaruh antar variabel laten. Tetapi, jika model belum baik perlu dilakukan modifikasi model.

\section{HASIL DAN PEMBAHASAN}

\subsection{Statistik Deskriptif}

Pengumpulan data menggunakan kuesioner Google Form. Selanjutnya, pemberitahuan kuesioner dikirim ke pengguna melalui surat elektronik sebanyak $\mathbf{5 0 0}$ orang pengguna secara acak. Dari $\mathbf{5 0 0}$ orang pengguna, 130 orang mengisi kuesioner secara lengkap. Jumlah responden tersebut terdiri dari 117 orang staf $(90 \%)$, dan 13 orang $(10 \%)$ pejabat struktural. Distribusi responden menurut asal instansi yaitu; internal Kementerian Keuangan sebanyak 5 orang (4\%) dan eksternal dari Kementerian/lembaga sebanyak 125 orang (96\%).

Menurut Hair et al. (1998) dalam Wiyono (2011) menyatakan bahwa para peneliti di Amerika Serikat menyetujui untuk menggunakan cara $5 \mathrm{x}$ jumlah item pertanyaan pada kuesioner untuk multivariate data analysis. Jadi jumlah sampel yang diperoleh sebanyak 130 responden sudah memenuhi syarat minimal penelitian ini yaitu sebesar 105 responden ( $5 \times 21$ pertanyaan).

Selain itu, sampel sebanyak $4 \%$ dari internal Kementerian Keuangan dan $96 \%$ berasal dari eksternal Kementerian Keuangan. Dengan demikian, sampel yang diperoleh dapat merepresentasi dari populasi, di mana pengguna OM SPAN internal Kementerian Keuangan sebanyak $4 \%$ dan eksternal Kementerian Keuangan sebanyak $96 \%$.

\subsection{Analisis Pengukuran Kesuksesan Pengukuran} tingkat kesuksesan menggunakan

kuesioner dengan skala 1-5. Hasil pengkuruan kesuksesan implementasi OM SPAN pada Lampiran II. Berdasarkan hasil pengukuran tersebut, rata-rata item pengukuran sebesar 4,15 pada skala 1-5. Selanjutnya, persentase tingkat kesuksesan didapatkan $83 \%$ (4,15/5 x 100\%). Berdasarkan Purwanto (2007) nilai $83 \%$ menunjukkan bahwa implementasi OM SPAN pada tingkat "Sangat sukses".

\subsection{Analisis Model}

\subsubsection{Uji validitas}

Uji validitas menggunakan AMOS versi 21, dengan acuan nilai loading factor lebih dari $\mathbf{0 . 5}$. Hasilnya, beberapa variabel dihapus dari model yaitu: IQ5, UI1, UI2 dan NB4 dikarenakan nilai loading factor kurang dari 0.5 .

Tabel 2. Assessment of normality

\begin{tabular}{|l|rrrrrr}
\hline Variable & $\min$ & $\max$ & skew & c.r. & kurtosis & c.r. \\
\hline SEQ3 & 2.000 & 5.000 & -.957 & -4.456 & 1.783 & 4.149 \\
SEQ2 & 2.000 & 5.000 & -1.206 & -5.615 & 2.600 & 6.051 \\
SEQ1 & 2.000 & 5.000 & -.865 & -4.027 & 2.764 & 6.434 \\
NB3 & 1.000 & 5.000 & -1.269 & -5.907 & 6.849 & 15.940 \\
NB2 & 1.000 & 5.000 & -1.322 & -6.154 & 6.110 & 14.219 \\
NB1 & 1.000 & 5.000 & -1.346 & -6.266 & 5.628 & 13.099 \\
US2 & 1.000 & 5.000 & -1.474 & -6.862 & 4.980 & 11.591 \\
US1 & 1.000 & 5.000 & -1.391 & -6.476 & 5.921 & 13.781 \\
SQ1 & 1.000 & 5.000 & -.990 & -4.609 & 1.723 & 4.010 \\
SQ2 & 1.000 & 5.000 & -1.480 & -6.891 & 4.018 & 9.352 \\
SQ3 & 1.000 & 5.000 & -1.513 & -7.042 & 4.572 & 10.642 \\
SQ4 & 1.000 & 5.000 & -1.191 & -5.546 & 1.228 & 2.858 \\
SQ5 & 1.000 & 5.000 & -1.333 & -6.203 & 6.921 & 16.108 \\
IQ4 & 1.000 & 5.000 & -1.847 & -8.598 & 5.590 & 13.009 \\
IQ3 & 1.000 & 5.000 & -1.837 & -8.551 & 7.521 & 17.504 \\
IQ2 & 1.000 & 5.000 & -1.813 & -8.437 & 5.595 & 13.022 \\
IQ1 & 1.000 & 5.000 & -2.038 & -9.487 & 5.931 & 13.804 \\
Multivariate & & & & & 229.735 & 51.529
\end{tabular}

\subsubsection{Uji normalitas}


Uji normalitas menggunakan AMOS versi 21, tampak dengan nilai kritikal (c.r.) antara -2.58 s.d 2.58. Hasilnya, data terdistribusi tidak normal tampak pada nilai c.r. di luar range -2.58 s.d 2.58.

\subsubsection{Uji model menggunakan PLS-SEM}

PLS-SEM merupakan salah satu teknik SEM yang mampu menganalisis variabel laten, variabel indikator, dan kesalahan pengukuruan secara langsung (Wiyono, 2011). Pada Smart PLS 3.0, uji model terdiri dari outer dan inner model (Wiyono, 2011). Pertama, outer model digunakan untuk mengukur hubungan antara variabel laten dengan indikatornya. Hasil uji outer model tampak pada Gambar 3 dan Tabel 3.

PLS-SEM merupakan salah satu teknik SEM yang mampu menganalisis variabel laten, variabel indikator, dan kesalahan pengukuruan secara langsung (Wiyono, 2011). Pada Smart PLS 3.0, uji model terdiri dari outer dan inner model (Wiyono, 2011). Pertama, outer model digunakan untuk mengukur hubungan antara variabel laten dengan indikatornya. Hasil uji outer model tampak pada Gambar 3 dan Tabel 3.

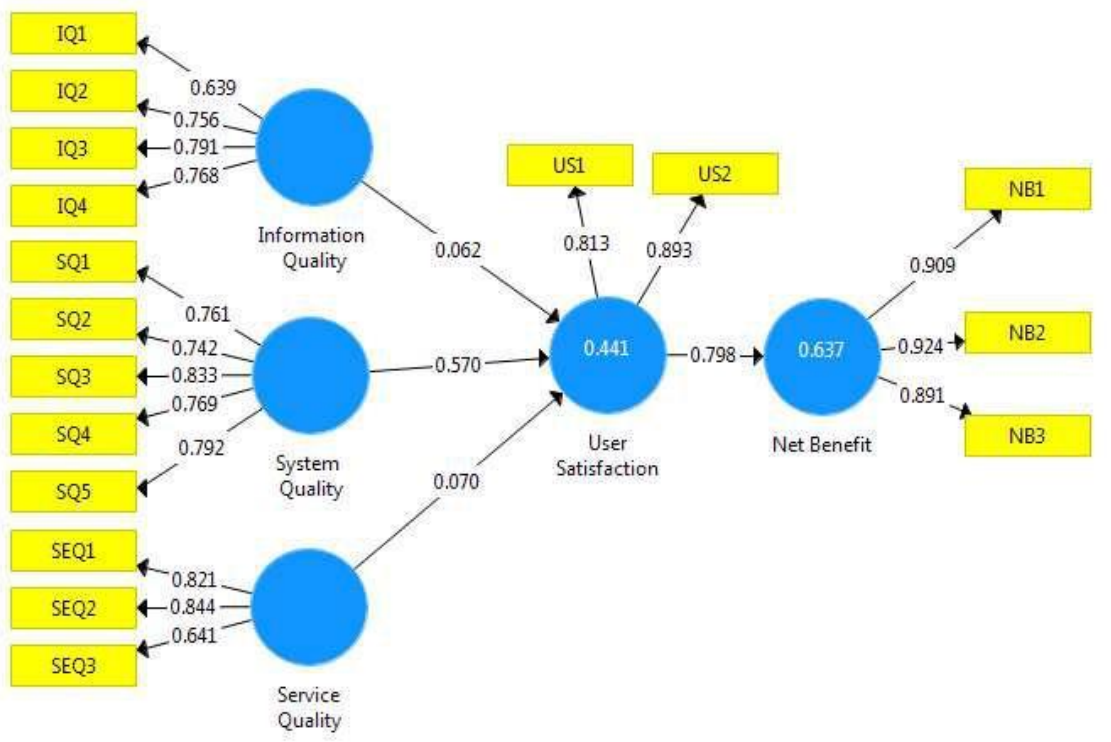

Gambar 1. Hasil Alogaritma PLS

\begin{tabular}{|c|c|c|c|c|c|c|c|c|c|}
\hline Indicators & IQ & NB & SEQ & SQ & US & Status & CR & AVE & $R^{2}$ \\
\hline IQ1 & 0.639 & 0.176 & 0.263 & 0.483 & 0.235 & Valid & \multirow{4}{*}{0.829} & \multirow{4}{*}{0.549} & \\
\hline IQ2 & 0.756 & 0.268 & 0.329 & 0.479 & 0.369 & Valid & & & \\
\hline IQ3 & 0.791 & 0.448 & 0.328 & 0.606 & 0.437 & Valid & & & \\
\hline IQ4 & 0.768 & 0.252 & 0.358 & 0.505 & 0.374 & Valid & & & \\
\hline NB1 & 0.349 & 0.909 & 0.352 & 0.545 & 0.767 & Valid & \multirow{3}{*}{0.934} & \multirow{3}{*}{0.824} & \\
\hline NB2 & 0.318 & 0.924 & 0.263 & 0.511 & 0.712 & Valid & & & 0.637 \\
\hline NB3 & 0.441 & 0.891 & 0.315 & 0.620 & 0.692 & Valid & & & \\
\hline SEQ1 & 0.367 & 0.292 & 0.821 & 0.601 & 0.406 & Valid & \multirow{3}{*}{0.815} & \multirow{3}{*}{0.599} & \\
\hline SEQ2 & 0.343 & 0.265 & 0.844 & 0.555 & 0.443 & Valid & & & \\
\hline SEQ3 & 0.302 & 0.246 & 0.641 & 0.394 & 0.231 & Valid & & & \\
\hline SQ1 & 0.559 & 0.427 & 0.543 & 0.761 & 0.436 & Valid & \multirow{5}{*}{0.886} & \multirow{5}{*}{0.609} & \\
\hline SQ2 & 0.588 & 0.292 & 0.549 & 0.742 & 0.424 & Valid & & & \\
\hline SQ3 & 0.614 & 0.567 & 0.559 & 0.833 & 0.548 & Valid & & & \\
\hline SQ4 & 0.464 & 0.398 & 0.706 & 0.769 & 0.509 & Valid & & & \\
\hline SQ5 & 0.525 & 0.640 & 0.344 & 0.792 & 0.619 & Valid & & & \\
\hline US1 & 0.469 & 0.522 & 0.410 & 0.561 & 0.813 & Valid & \multirow[b]{2}{*}{0.843} & \multirow[b]{2}{*}{0.729} & \multirow[b]{2}{*}{0.441} \\
\hline US2 & 0.385 & 0.811 & 0.419 & 0.572 & 0.893 & Valid & & & \\
\hline
\end{tabular}

Berdasarkan Gambar 3 dan Tabel 3, dapat dijelaskan sebagai berikut:

1) Loading factors. Nilai loading factor semua variabel dalam model lebih dari 0.5 . Artinya bahwa semua variabel pada model ini sudah memenuhi syarat.

2) Discriminant validity. Valid, jika nilai discriminant validity atau korelasi cross loading dengan variabel latennya harus lebih besar dari korelasi terhadap variabel laten yang lain (Wiyono, 2011). Hasil pengkuruan model menunjukkan nilai korelasi cross loading dengan variabel latennya lebih besar dari korelasi terhadap variabel laten yang lain, berarti bahwa variabel pada model ini sudah memenuhi syarat.

3) Average Variance Extracted (AVE). Valid, jika nilai AVE di atas 0.50 (Wiyono, 2011). Hasil pengkuruan model menunjukkan nilai AVE di atas 0.50 , berarti bahwa variabel laten pada model ini sudah memenuhi syarat.

4) Composite Reliability (CR). Nilai CR yang baik jika $\geq 0.70$ (Wiyono, 2011). Hasil pengkuruan model menunjukkan nilai $C R$ di atas 0.70 , berarti bahwa 
semua variabel laten pada model ini sudah memenuhi syarat atau dapat diandalkan.

\begin{tabular}{ccccc} 
& \multicolumn{4}{c}{ Tabel 2. Uji Pengaruh } \\
\hline Hipotesis & $\boldsymbol{\beta}$ & $\begin{array}{c}\mathrm{t}- \\
\text { statistic }\end{array}$ & Analisa $\boldsymbol{\beta}$ & $\begin{array}{c}\text { Uji } \\
\text { hipotesis }\end{array}$ \\
\hline IQ -> NB & 0.049 & 0.526 & $\begin{array}{c}\text { Tidak } \\
\text { signifikan }\end{array}$ & Ditolak \\
\hline IQ -> US & 0.062 & 0.531 & $\begin{array}{c}\text { Tidak } \\
\text { signifikan }\end{array}$ & Ditolak \\
\hline SEQ -> NB & 0.056 & 0.366 & $\begin{array}{c}\text { Tidak } \\
\text { signifikan }\end{array}$ & Ditolak \\
\hline SEQ -> US & 0.070 & 0.345 & $\begin{array}{c}\text { Tidak } \\
\text { signifikan }\end{array}$ & Ditolak \\
\hline SQ -> NB & 0.455 & 2.402 & signifikan & Diterima \\
\hline SQ -> US & 0.570 & 2.645 & signifikan & Diterima \\
\hline US $>>$ NB & 0.798 & 13.070 & signifikan & Diterima \\
\hline & & & & \\
\hline
\end{tabular}

Kedua, inner model digunakan untuk mengukur pengaruh antar variabel laten pada model. Hasil uji inner model tampak pada Tabel 4.

Berdasarkan Gambar 3, Tabel 3 dan Tabel 4, dapat dijelaskan sebagai berikut:

a. $\mathbf{R}$ square $\left(\mathbf{R}_{2}\right)$. $\mathbf{R}$ square atau koefisien determinasi digunakan untuk mengetahui proporsi variasi keseluruhan dalam nilai variabel dependen yang dapat diterangkan oleh hubungan linear dengan variabel independen (Supardi, 2012). Hasil R square memiliki arti bahwa; 0.67 (baik), 0.33 (moderat) dan 0.19 (lemah) (Wiyono, 2011). Berdasarkan tabel 2, nilai $\mathbf{R}_{2}$ variabel laten Net Benefit sebesar 0.637 (63,7\%). Artinya bahwa manfaat bersih yang didapatkan pengguna dipengaruhi oleh kepuasan pengguna sebesar $63.7 \%$ dan sisanya $36.3 \%$ dipengaruhi oleh faktor lain. Nilai $\mathbf{R}_{2}$ variabel laten User Satisfaction sebesar 0.441 (44.1\%). Artinya bahwa kepuasan pengguna dipengaruhi oleh faktor kualitas informasi, sistem dan layanan secara bersama sebesar $44.1 \%$ dan sisanya $55.9 \%$ dipengaruhi oleh faktor lain. Nilai kedua $\mathrm{R}_{2}$ diantara $0.33-0.67$, berarti bahwa pengaruh variabel dalam model pada tingkat moderat.

b. Path coefficients ( $\beta$ ). Path coefficients atau koefisien jalur digunakan untuk mengetahui nilai estimasi hubungan jalur pada model struktural (Wiyono, 2011). Berdasarkan tabel 3 , semua bernilai positif dengan 3 dari 7 jalur berpengaruh signifikan.

Structural path significance. Structural path significance digunakan untuk mengetahui signifikasi pengaruh variabel eksogen dan endogen terhadap variabel endogen (Wiyono, 2011). Structural path significance dapat dilakukan dengan menggunakan bootstrapping PLS dan membandingkan antara nilai $t_{\text {-tabel }}$ (1.985) dengan $t$ - statistik pada level signifikasi $5 \%$. Berdasarkan Tabel 4, 3 dari 7 hipotesis diterima dan yang lainnya ditolak

\subsection{Pembahasan}

Hasil pengukuran kesuksesan implementasi OM SPAN pada tingkat $83 \%$. Berdasarkan Purwanto (2007) tingkat tersebut temasuk pada tingkat "Sangat Sukses". Kesuksesan implementasi OM SPAN pada tingkat "Sangat Sukses" ini didukung oleh beberapa faktor. Faktor-faktor pendukung tersebut adalah kualitas informasi, kualitas sistem informasi, kualitas layanan, kepuasan pengguna dan manfaat bersih yang diterima pengguna.

Selanjutnya, hubungan antara faktor-faktor pendukung kesuksesan implementasi OM SPAN adalah:

a. Pengaruh kualitas informasi terhadap kepuasan pengguna. Hasil pengujian dan analisis data menunjukkan bahwa kualitas informasi tidak berpengaruh terhadap kepuasan pengguna. Hal ini berarti bahwa hipotesis 1 ditolak. Hasil penelitian ini berbeda dengan (Livari, 2005), (Istianingsih \& Wijanto, 2008), (Wahyuni, 2011), (Utami \& Samopa, 2013), dan (Kanwal \& Rehman, 2016). Hasil ini menunjukkan bahwa kualitas informasi yang disajikan OM SPAN sudah baik dengan rata-

rata skor 4,28 $(,,,,$,$) dari skala 1-5.$ Sehingga, pengguna merasa puas dan mendapatkan manfaat dari informasi tersebut.

b. Pengaruh kualitas sistem informasi terhadap kepuasan pengguna dan manfaat bersih bagi pengguna. Hasil pengujian dan analisis data menunjukkan bahwa kualitas sistem informasi secara langsung pengaruh positif signifikan terhadap kepuasan pengguna. Hasil penelitian ini sesuai dengan (Livari, 2005) (Livari, 2005), (Istianingsih \& Wijanto, 2008), (Wahyuni, 2011), (Utami \& Samopa, 2013), dan (Kanwal \& Rehman, 2016).

Selain itu, kualitas sistem informasi secara tidak langsung juga berpengaruh positif signifikan terhadap manfaat bersih bagi pengguna. Hal ini berarti bahwa hipotesis 4 diterima. Hasil penelitian ini sesuai dengan (Livari, 2005) dan (Utami \& Samopa, 2013). 
Hasil pengukuran kualitas sistem informasi berdasarkan Purwanto (2007) menunjukkan nilai

baik dengan rata-rata $4,16(,,,,$, dari skala 1-5. Hal ini mendukung kesuksesan implementasi OM SPAN. Namun demikian, jika kualitas sistem informasi ini ditingkatkan akan memberikan dampak pada peningkatan kepuasan pengguna dan manfaat bersih yang diterimanya.

c. Pengaruh kualitas layanan terhadap kepuasan pengguna. Hasil pengujian dan analisis data menunjukkan bahwa kualitas layanan tidak berpengaruh terhadap kepuasan pengguna. Hal ini berarti bahwa hipotesis 6 ditolak. Hasil penelitian ini sesuai dengan (Sedera, Gable, \& Chan, 2004), namun berbeda dengan hasil penelitian (Petter, Delone, \& McLean, 2008), (DeLone \& McLean, 2003), dan (Utami \& Samopa, 2013). Hasil ini menunjukkan bahwa kualitas layanan yang diberikan terkait OM SPAN sudah baik dengan rata-

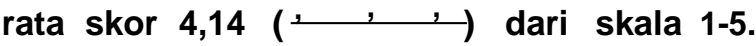
Sehingga, pengguna merasa puas dan mendapatkan manfaat dari layanan tersebut.

d. Pengaruh kepuasan pengguna terhadap manfaat bersih bagi pengguna. Hasil pengujian dan analisis data menunjukkan bahwa kepuasan pengguna berpengaruh positif signifikan terhadap manfaat bersih bagi pengguna. Hal ini berarti bahwa hipotesis 7 diterima. Hasil penelitian ini sesuai dengan (DeLone \& McLean, 2003) dan (Utami \& Samopa, 2013). Hasil ini menunjukkan bahwa kepuasan pengguna yang didapatkan dari kualitas informasi, kualitas sistem informasi dan kualitan layanan memiliki peran penting pada manfaat yang diterima pengguna. Peningkatan yang terjadi pada kepuasan pengguna akan berdampak pada peningkatan manfaat yang diterimanya.

e. Pengaruh penggunaan terhadap manfaat bersih bagi pengguna. Hasil pengujian dan analisis data menunjukkan bahwa penggunaan (use) dieliminasi dari model. Hal ini berarti bahwa hipotesis 1, 3, 5 , dan 7 ditolak. Hasil penelitian ini sesuai dengan (Sedera, Gable, \& Chan, 2004), namun berbeda dengan hasil penelitian (DeLone \& McLean, 2003) dan (Utami \& Samopa, 2013). Hasil ini mengkonfirmasi hasil (Sedera, Gable, \& Chan, 2004), di mana jika objek penelitian merupakan sistem informasi bersifat mandatori, maka instrumen pengukuran penggunaan tidak relevan dan dikeluarkan dari model. Hal ini memberikan informasi bahwa banyak sedikitnya pengguna dan frekuensi penggunaan ditentukan oleh kebijakan untuk menggunakan OM SPAN.

\section{KESIMPULAN}

Simpulan dari hasil penelitian ini adalah Kementerian Keuangan RI sangat sukses mengimplementasikan OM SPAN. Sedangkan faktor-faktor yang mendukung kesuksesan implementasi tersebut adalah kualitas informasi, kualitas sistem informasi, kualitas layanan, dan kepuasan pengguna.

Faktor pertama, kualitas informasi tidak berpengaruh terhadap kepuasan pengguna maupun manfaat bersih bagi pengguna. Artinya bahwa, peningkatan atau penurunan kualitas informasi tidak akan berpengaruh banyak pada kepuasan pengguna maupun manfaat bersih yang diterimanya.

Faktor kedua, faktor kualitas sistem informasi pengaruh positif signifikan terhadap kepuasan pengguna dan manfaat bersih bagi pengguna. Artinya bahwa, peningkatan kualitas sistem informasi akan meningkatkan kepuasan dan manfaat bersih yang diterima pengguna.

Faktor ketiga, kualitas layanan tidak berpengaruh terhadap kepuasan pengguna maupun manfaat bersih bagi pengguna. Artinya bahwa, peningkatan atau penurunan kualitas layanan tidak akan berpengaruh terhadap kepuasan pengguna maupun manfaat bersih yang diterimanya.

Faktor keempat, kepuasan pengguna berpengaruh positif signifikan terhadap manfaat bersih bagi pengguna. Artinya bahwa, peningkatan kepuasan pengguna akan meningkatkan manfaat bersih bagi pengguna.

\section{IMPLIKASI DAN KETERBATASAN}

Keterbatasan dalam penelitian ini dalam jumlah sampel sebanyak 130 responden, sedangkan populasi mencapai 50-an ribu pengguna. Namun demikian, penelitian ini dilanjutkan karena karakteristik pengguna yang relatif homogen, di mana mereka adalah pengelolaan ABPN dengan akses dan pemahaman teknologi informasi yang relatif sama.

Implikasi dari hasil penelitian ini adalah:

a. Penelitian mendatang dapat menggunakan IS Success model untuk meningkatkan validitas dan model riset, baik basis teori maupun penerapan empirisnya, khususnya dikaitkan dengan kondisi lokal.

b. Faktor kualitas informasi dan layanan OM SPAN sudah baik. Dengan demikian jika oganisasi organisasimengambilkebijakanuntuk 
meningkatkan kedua faktor tersebut, tidak berpengaruh terhadap kepuasan dan manfaat bersih yang diperoleh pengguna.

c. Faktor kualitas sistem informasi berpengaruh signifikan terhadap kepuasan dan manfaat bersih yang diterima pengguna. Hal ini dapat digunakan organisasi untuk menyusun kebijakan dalam pengembangan OM SPAN terkait peningkatan kualitas sistem informasinya.

\section{REKOMENDASI}

Rekomendasi yang dapat disampaikan penulis berdasarkan uraian sebelumnya adalah:

a. Bagi pengelola OM SPAN, pengembangan OM SPAN dapat difokuskan pada peningkatan kualitas sistem informasi agar meningkatkan kepuasan pengguna dan manfaat bagi pengguna. Pengembangan kualitas sistem informasi tersebut terutama pada aspek kecepatan merespon permintaan (response time) dan fleksibilitas sistem.

b. Bagi satuann kerja atau organisasi pemerintah yang belum menggunakan OM SPAN agar segera menggunakannya untuk memudahkan dalam pengelolaan APBN.

\section{DAFTAR PUSTAKA}

Bacon, L. D, 2009. Using AMOS for structural equation modeling in market research. Lynd Bacon \& Associates.

Baroudi, J., Olson, M., Ives, B., 1986. An Empirical Study of the Impact of User Involvement on System Usage and Information Satisfaction. Communications of the ACM p 232-238.

Bowen, N. K., Guo, S., 2011. Structural Equation Modeling. Oxford Scholarship.

Davis, F. D., 1989. Perceived Ease of Use, and User Acceptance of Information Technology. Management Information Systems Quality Journal Volume 13 No.3 p 319-340.

DeLone, W. H., McLean, E. R., 1992. Information Systems Success: The Quest for the Dependent Variable. Information System Resource Volume 3 No.4 p 60-95.

DeLone, W. H., McLean, E. R., 2003. The DeLone andMcLean Model of Information Systems Success : A Ten-Year Update. Journal of Management Information Systems Volume 19 No.4 p 9-30.
Furukawa, M., Minami, A., 2013. A Study on the 'Flexibility' of Information Systems (Part 1): Why Do They Need to Be Flexible?. International Journal of Business and Management Volume 8 No.20 p 48-61.

Garson, G. D., 2016. Partial least squares: regression \& structural equation models. North Carolina: Statistical Publishing Associates.

Gelinas, U., Dull, B. R., 2012. Accounting Information Systems. Natorp Boulevard Mason: South Western Cengage Learning.

Ghozali, I., 2008. Model Persamaan Struktural Konsep dan Aplikasi dengan Program Amos 16.0. Semarang: Badan Penerbit UNDIP.

Hall, J. A., 2011. Accounting Information System. USA: South-Western Cengage Learning.

Istianingsih, Wijanto, S. H., 2008. Analisis Keberhasilan Penggunaan Perangkat Lunak Akuntansi Ditinjasu Dari Persepsi Pemakai (Studi Implementasi Model Keberhasilan Sistem Informasi). Jurnal Akuntansi dan Keuangan Indonesia Volume 5 No.1 p 50-76.

Jogiyanto, H., 2007. Model Kesuksesan Sistem Teknologi Informasi. Yogyakarta: Andi Publisher.

Kanwal, F., Rehman, M., 2016. Measuring information, system and service qualities for the evaluation of e-learning systems in pakistan. Pakistan Journal of Science Volume 68 No.3 p 302-307.

Livari, J., 2005. An Empirical Test of the Model of Information System Success. DATA BASE Adv. Inf. Syst, 8-27.

McGill, T., Hobbs, V., Klobas, J., 2003. Users Developed Application and Information System Success: A Test of Delone and McLean's Model. Information Resource Management Journal Volume 16 No.1 p $24-45$.

Petter, S., Delone, W., McLean, E., 2008. Measuring information systems success: model, dimension, measures, and interrelationships". European Journal of Information Systems p 236-263.

Pramadani, R., Mudjahidin, 2013. Analisis Keberhasilan E-procurement Pemerintah Kota Surabaya Menggunakan Information System Success Model. Jurnal Teknik POMITS Volume 1 No.1 p 1-6. 
Purwanto, A., 2007. Rancangan dan Implementasi Model Pemeriksaan Kinerja BPK RI Atas Aplikasi e-Government di Pemerintah Daerah: Kabupaten Sragen. Yogyakarta: Universitas Gajah Mada.

Radityo, D., Zulaikha., 2007. Pengujian Model DeLone dan McLean dalam Pengembangan Sistem Informasi Manajemen: Kajian Sebuah Kasus. SNA. Solo: IAI.

Sedera, D., Gable, G., Chan, T., 2004. A factor and structural equation analysis of the enterprise systems success measurement model. In Proceedings of the Twenty-Fifth International Conference on Information Systems p 449. Washington DC: Association for Information Systems.

Stair, M. R., Reynolds, G. W., 2010. Principles of Information Systems: A Managerial Approach. Australia : Thomson Course Technology.

Sulistyo, G. B., 2013. Efektivitas Penggunaan E-Learning Moodle Sebagai Media Pembelajaran Terhadap Nilai Siswa di SMK Ma'Arif Kota Mungkid. Jurnal Bianglala Informatika Volume 1 No.2 p 2028.

Supardi, 2012. Aplikasi Statistik Dalam Penelitian. Jakarta: UFUK PRESS.

Undang-Undang Republik Indonesia Nomor 17 Tahun 2003 Tentang Keuangan Negara. Jakarta: Sekretariat Negara RI
Utami, A. W., Samopa, F., 2013. Analisis Kesuksesan Sistem Informasi Akademik (SIAKAD) di Perguruan Tinggi dengan menggunakan D\&M IS Success Model: ITS Surabaya. Jurnal Sistem Informasi Volume 4 No.5 p 294-309.

Wahyuni, T., 2011. Uji Empiris Model Delone dan Mclean Terhadap Kesuksesan. Sistem Informasi Manajemen Daerah (SIMDA). Jurnal Badan Pendidikan dan Pelatihan Keuangan Volume 2 No. 1 p 3-25.

Wiyono, G., 2011. Merancang Penelitian Bisnis dengan Alat Analisis SPSS 17.0 dan SmartPLS 2.0. Yogyakarta: UPP STIM YKPN. 


\section{LAMPIRAN I}

\section{KUESIONER PENELITIAN}

\begin{tabular}{|c|c|c|c|c|}
\hline No & Variabel & Indikator & Kode & Kuesioner \\
\hline \multirow{5}{*}{1} & \multirow{5}{*}{$\begin{array}{c}\text { Information } \\
\text { Quality } \\
\text { (Livari, 2005) }\end{array}$} & Completeness & IQ1 & $\begin{array}{l}\text { Dari OM SPAN/SPAN, Saya mendapatkan data yang lengkap sesuai } \\
\text { dengan kebutuhan pekerjaan saya }\end{array}$ \\
\hline & & Precision & IQ2 & $\begin{array}{l}\text { Dari OM SPAN/SPAN, Informasi yang saya dapatkan sesuai dengan } \\
\text { keadaan sebenarnya. }\end{array}$ \\
\hline & & Relevance & IQ3 & $\begin{array}{l}\text { Saya dapat mengandalkan data yang didapatkan dari OM } \\
\text { SPAN/SPAN untuk mendukung pekerjaan saya di kantor }\end{array}$ \\
\hline & & Currency & IQ4 & $\begin{array}{l}\text { Data yang saya dapat dari OM SPAN/SPAN adalah informasi terkin } \\
\text { (up-to date) dan selalu diperbarui. }\end{array}$ \\
\hline & & Format of Output & IQ5 & $\begin{array}{l}\text { Data yang saya dapat dari OM SPAN/SPAN dapat di ekspor } \\
\text { kemudian digunakan di aplikasi atau media lain. }\end{array}$ \\
\hline \multirow{5}{*}{2} & \multirow{5}{*}{$\begin{array}{c}\text { System Quality } \\
\text { (Livari, 2005) }\end{array}$} & System Flexibility & SQ1 & $\begin{array}{l}\text { OM SPAN/SPAN dapat di kostumisasi sesuai dengan kebutuhan } \\
\text { saya. }\end{array}$ \\
\hline & & System Integration & SQ2 & OM SPAN/SPAN selalu tersedia untuk diakses. \\
\hline & & Reliability & SQ3 & $\begin{array}{l}\text { Saya dapat mengandalkan OM SPAN/SPAN dalam mendukung } \\
\text { perkerjaan saya. }\end{array}$ \\
\hline & & Time To Respon & SQ4 & $\begin{array}{l}\text { Waktu respon (response time) OM SPAN/SPAN sesuai dengan } \\
\text { harapan saya. }\end{array}$ \\
\hline & & $\begin{array}{l}\text { Convenience of } \\
\text { Access }\end{array}$ & SQ5 & OM SPAN/SPAN berguna untuk mendukung pekerjaan saya. \\
\hline \multirow{3}{*}{3} & \multirow{3}{*}{$\begin{array}{l}\text { Service Quality } \\
\text { (DeLone \& } \\
\text { McLean, 2003) }\end{array}$} & Assurance & SEQ1 & Saya dapat dengan mudah menggunakan layanan OM SPAN/SPAN \\
\hline & & Emphaty & SEQ2 & $\begin{array}{l}\text { Layanan yang diberikan OM SPAN/SPAN sesuai dengan harapan } \\
\text { saya. }\end{array}$ \\
\hline & & Responsiveness & SEQ3 & $\begin{array}{l}\text { OM SPAN/SPAN memberikan tanggapan sesuai dengan apa yang } \\
\text { saya perintahkan }\end{array}$ \\
\hline \multirow{2}{*}{4} & \multirow{2}{*}{$\begin{array}{c}\text { Use } \\
\text { (Livari, 2005) }\end{array}$} & Daily Used Time & Ul1 & $\begin{array}{l}\text { Saya sering mengakses OM SPAN/SPAN untuk mendapatkan data } \\
\text { keuangan instansi tempat saya bekerja }\end{array}$ \\
\hline & & Frequency of Use & UI2 & $\begin{array}{l}\text { Ketika mengakses OM SPAN, saya mengaksesnya dalam jangka } \\
\text { waktu yang lama }\end{array}$ \\
\hline \multirow[b]{2}{*}{5} & \multirow{2}{*}{$\begin{array}{c}\text { User } \\
\text { Satisfaction } \\
\text { (DeLone \& } \\
\text { McLean, 2003) }\end{array}$} & Repeat Purchase & US1 & Saya puas dengan data yang saya dapatkan dari OM SPAN/SPAN. \\
\hline & & Repeats Visits & US2 & $\begin{array}{l}\text { Dengan OM SPAN/SPAN, saya dapat menyelesaikan pekerjaan saya } \\
\text { dengan lebih cepat. }\end{array}$ \\
\hline \multirow{4}{*}{6} & \multirow{4}{*}{$\begin{array}{l}\text { Net Benefit } \\
\text { (Davis, 1989) }\end{array}$} & $\begin{array}{l}\text { Speeds of } \\
\text { accomplishing task }\end{array}$ & NB1 & $\begin{array}{l}\text { Dengan OM SPAN/SPAN, saya dapat menyelesaikan pekerjaan saya } \\
\text { dengan lebih baik. }\end{array}$ \\
\hline & & Effectiveness & NB2 & Dengan OM SPAN/SPAN, saya dapat lebih efektif dalam bekerja. \\
\hline & & Ease of Job & NB3 & Dengan OM SPAN/SPAN, saya merasa lebih mudah dalam bekerja. \\
\hline & & Usefullness in Work & NB4 & $\begin{array}{l}\text { OM SPAN/SPAN sangat berguna dalam menyelesaikan pekerjaan } \\
\text { dan kegiatan organisasi. }\end{array}$ \\
\hline
\end{tabular}




\section{LAMPIRAN II}

HASIL TANGGAPAN RESPONDEN

\begin{tabular}{|c|c|c|c|c|c|c|}
\hline Pengukuran & $\begin{array}{c}\text { Sangat } \\
\text { setuju } \\
(5) \\
\end{array}$ & $\begin{array}{l}\text { Setuju } \\
(4)\end{array}$ & $\begin{array}{c}\text { Tidak } \\
\text { tahu } \\
(3) \\
\end{array}$ & $\begin{array}{c}\text { Tidak } \\
\text { setuju } \\
(2) \\
\end{array}$ & $\begin{array}{l}\text { Sangat tidak } \\
\text { setuju } \\
\text { (1) }\end{array}$ & Rata-rata*) \\
\hline IQ1 & 59 & 65 & 0 & 3 & 3 & 4,34 \\
\hline IQ2 & 54 & 70 & 1 & 3 & 2 & 4,32 \\
\hline IQ3 & 57 & 69 & 2 & 0 & 2 & 4,38 \\
\hline IQ4 & 57 & 67 & 1 & 3 & 2 & 4,34 \\
\hline IQ5 & 33 & 74 & 16 & 6 & 1 & 4,02 \\
\hline SQ1 & 23 & 82 & 17 & 7 & 1 & 3,92 \\
\hline SQ2 & 39 & 83 & 1 & 6 & 1 & 4,18 \\
\hline SQ3 & 54 & 70 & 2 & 3 & 1 & 4,33 \\
\hline SQ4 & 31 & 78 & 5 & 14 & 2 & 3,94 \\
\hline SQ5 & 57 & 72 & 0 & 0 & 1 & 4,42 \\
\hline SEQ1 & 45 & 81 & 1 & 3 & 0 & 4,29 \\
\hline SEQ2 & 33 & 87 & 2 & 8 & 0 & 4,12 \\
\hline SEQ3 & 26 & 87 & 10 & 7 & 0 & 4,02 \\
\hline Ul1 & 58 & 71 & 0 & 1 & 0 & 4,43 \\
\hline UI2 & 12 & 45 & 8 & 52 & 13 & 2,93 \\
\hline US1 & 43 & 83 & 1 & 2 & 1 & 4,27 \\
\hline US2 & 40 & 84 & 1 & 4 & 1 & 4,22 \\
\hline NB1 & 41 & 84 & 2 & 2 & 1 & 4,25 \\
\hline NB2 & 33 & 91 & 3 & 2 & 1 & 4,18 \\
\hline NB3 & 40 & 87 & 1 & 1 & 1 & 4,26 \\
\hline NB4 & 33 & 78 & 9 & 6 & 4 & 4,00 \\
\hline \multicolumn{6}{|c|}{ Rata-rata item pengukuran ${ }^{\star *}$ ) } & 4,15 \\
\hline \multicolumn{6}{|c|}{ Persentase tingkat kesuksesan $\left.{ }^{\star \star \star}\right)=\left(\begin{array}{c}\begin{array}{c}\text { Rata-rata item pengukuran } \\
\text { Nilai Maksimal }\end{array}\end{array}\right) \times 100 \%$} & $83 \%$ \\
\hline
\end{tabular}

\section{Keterangan:}

*) Rata-rata IQ1 $=(\quad)(\quad)(\quad)(\quad)(\quad)=4,34$

$\left.{ }^{* *}\right)$ Rata-rata item pengukuran $=$

$$
=4,15
$$

${ }^{* * *}$ ) Persentase tingkat kesuksesan $=-, \times 100 \%=83 \%$ 